\title{
室戸沖南海トラフ付加体前縁部の高熱流量と 地下深部の圧力・浸透率の関係
}

\author{
藤 野 恵子* 木下 正 高** \\ Localized High Heat Flow Anomaly at the Frontal Thrust \\ in the Nankai Trough off Muroto: \\ Relationship between Pressure and Permeability \\ in a Deep Part of the Accretionary Prism \\ Keiko FUJINO* and Masataka KINOSHITA**
}

\begin{abstract}
The Nankai Trough is a convergent plate boundary where the Shikoku Basin subducts beneath southwest Japan. Turbidite and hemipelagic sediments on the trough floor form an accretionary prism landward of the trough axis through a process of sediment compaction. Near the toe of the accretionary prism, a series of frontal thrusts have formed above the decollement, which is a major slipping plane on the plate boundary.

In 2002, we discovered an extremely high heat flow at the second frontal thrust near the toe of the Nankai Trough off Muroto using ROV KAIKO during the KR02-10 research cruise of the Japan Agency for Marine-Earth and Technology (JAMSTEC). The background heat flow value was $160 \mathrm{~mW} / \mathrm{m}^{2}$ and high values of $250-280 \mathrm{~mW} / \mathrm{m}^{2}$ were obtained within $50 \mathrm{~m}$ above the second frontal thrust. The heat flow gradually decreases landward from this location.

A simple numerical calculation was carried out to test the hypothesis that the heat flow anomaly is caused by an interstitial fluid flow through the decollement/frontal thrust system as a permeable channel. Two parameters - permeability within the fault zone $\left(K_{c h}\right)$ and excess pore pressure $(\Delta P)$ - at the landward boundary of the decollement were adjusted to produce the bestfit combination to explain the observed heat flow anomaly.

The simulation result of 500 combination patterns indicates that $K_{c h}$ and $\Delta P$ cannot be determined independently. Instead, only their product $\left(K_{c h} \times \Delta P\right)$ can be estimated. The best-fit result, simulating the highest heat flow of $280 \mathrm{~mW} / \mathrm{m}^{2}$ was achieved where the product $K_{c h} \times \Delta P$ is $8 \times 10^{15}$, with a surrounding permeability of $10^{-17} \mathrm{~m}^{2}$. Based on the estimation of excess pore pressure in the decollement of less than $4 \mathrm{MPa}$, the most appropriate value of channel permeability is estimated to be higher than $2 \times 10^{-15} \mathrm{~m}^{2}$. Our numerical result is generally consistent with the previously estimated fracture permeability, i.e. three orders of magnitude higher than that of ambient sediment. Thus, we attribute the surface heat flow anomaly to the influence of the fluid flow through the permeable channel along the frontal thrust.
\end{abstract}

\footnotetext{
* 九州大学大学院工学府

** 独立行政法人海洋研究開発機構地球内部ダイナミクス領域

* Faculty of Engineering, Kyushu University, Fukuoka, 819-0395, Japan

** Institute for Research on Earth Evolution, Japan Agency for Marine-Earth Science and Technology, Kanagawa, 2370061, Japan
} 
Key words : high heat flow, pore pressure anomaly, frontal thrust, cold seepage, Nankai Trough, accretionary prism

キーワード：高熱流量，間隙水圧異常，前縁断層，冷湧水，南海トラフ，付加体

\section{I. はじめに}

南海トラフは，フィリピン海プレートの一部で ある四国海盆がユーラシアプレートの一部である 西南日本弧下に沈み込むプレート収束境界である （図 1)。沈み込む四国海盆の年齢は $15 \sim 25 \mathrm{Ma}$ と比較的若く，過去のプレート拡大軸が室戸岬沖 に沈み込んでいる。トラフ底には厚さが $1 \mathrm{~km}$ を 超える堆積層が存在し，その上部が付加体を形成 している。南海トラフ付加体では，これまで地形 調査や地震波構造探査, 試料採取, 潜水調査が精 力的に行われている。媣海掘削計画 (Deep Sea Drilling Project, DSDP) や国際深海掘削計画 (Ocean Drilling Program, ODP) による科学掘 削が実施されている。その結果, 室戸岬沖では, 四国海盆の基盤岩の年令が $15 \sim 14 \mathrm{Ma（Taira}$ et al., 1991）と判明した。また，付加体形成に伴 う前縁断層やすべり面であるデコルマの構造・性 質が明らかになってきた（例えば Mikada et al., 2005)。そのほか，四国海盆の拡大軸の沈み込む 室戸岬沖には，四国海盆拡大終了の後の 7 $10 \mathrm{Ma}$ に火成活動のあった紀南海山列が存在し ている（石井ほか, 2000）。

付加体の形成・発達過程を論じる上で, 堆積物 の性質やプレート収束速度は重要な要素である が，これに加えて付加体内部の水理特性，とくに 間隙流体の排出様式も重要な要素である。さら に，南海トラフ地震発生帯では $M 8.0$ 以上の巨大 地震が繰り返し発生する場所であり，間隙流体の 挙動が地震発生に及ぼす影響が大きいことが指摘 されている（笠原ほか, 2003）。

間隙流体の排出を規定するのは，間隙圧異常分

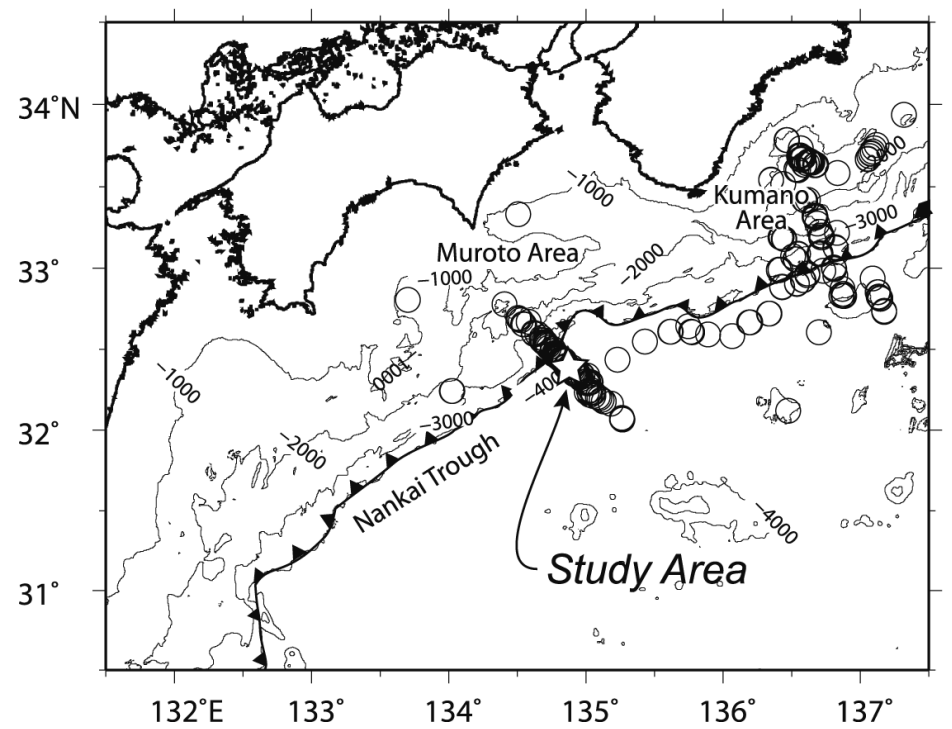

図 1 南海トラフ周辺の熱流量観測点の分布. 星型は本論で示す研究対象領域の室戸沖南海トラフ付加体先端 部の位置.図中の円型は現在まで測定された熱流量の観測点 (Yamano et al., 2003).

Fig. 1 Location of heat flow survey in the Nankai Trough off Cape Muroto (star). Circles indicate locations of previous heat flow measurements (Yamano et al., 2003). 
布，そして水理特性である。後者に関しては，前 縁断層やデコルマは周囲に比べて透水性が高いと 考えられており (Carson and Screaton, 1998; Kato et al., 2004)，間隙流体排出時の流路となるであ ろう。Taira et al.（1992）は，南海トラフで採 取された間隙流体中の無機化合物の結果から，付 加体のなかからデコルマに沿った流体の注入が あったことを示唆している。

熱流量の観測結果からも，南海トラフでは局 所的な高熱流量はデコルマ帯に沿った水の流れ によってもたらされた可能性が示唆されている (Yamano et al., 1992)。

こうした背景に基づき，南海トラフ室戸沖付加 体前縁部での間隙流体の湧出の規模と様式を推定 するために，われわれは潜水船を用いた高密度 熱流量マッピングを行っている。2002 年，この マッピングの一環として海洋科学技術センター （現，海洋研究開発機構。以下 JAMSTEC）で行 われた航海（KR02-10）では，無人探査機「かい こう」により, 室戸沖南海トラフの付加体前縁部 で熱流量観測を行った。本論では，この観測で得 た表層熱流量分布を報告し，定常流による間隙流 体の湧出が存在している付加体深部で発生してい る圧力変動, 流路となる場所と周辺の浸透率の関 係について数值シミュレーションを行った結果を 紹介する。そして，これに基づいて過剩間隙水圧 と熱流量の変動について議論する。

\section{II. 南海トラフ沈み込み帯周辺における 海底湧出現象}

南海トラフの軸部付近では四国海盆上の半遠洋 性堆積物の上にタービダイトが多量に堆積し, こ れらの堆積物が沈み込みの過程で四国海盆側から 剥ぎとられ，陸側に押し付けられ，付加体を形成 している。付加体の形成過程で，付加体前縁部に 沈み込みによる圧縮で前縁断層 (frontal thrust) が形成されている。付加体はその楔形の形状が臨 界尖形に達するまで，破壊と成長を繰り返してい ると考えられており（芦・平, 1989 など), 南海 トラフ付加体は現在も変形過程にある付加体であ る。
潜水調査の結果，南海トラフ付加体では，前縁 断層の出口付近で，シロウリガイ，バクテリア マット，ハオリムシなど湧水起源の化学合成生態 系生物群集が発見されている（南海トラフ熊野 沖では芦ほか (2002) や Fiala-Médioni et al. (1993), Toki et al. (2004)，東部南海トラフ周 辺では Le Pichon et al.（1987）による報告）。 こうした化学合成生態系生物群集のコロニーは, 熊野沖では断層の基部から中腹にかけての緩斜 面，斜面の凹地，または平坦面に溜まった泥質堆 積物上に発見されている。東部南海トラフ天竜海 底谷付近では観測された温度勾配が通常の日本縁 辺の約 100 倍の高異常，6〜10 倍の高メタン濃 度異常も確認され，流体の上昇が示唆されている (Le Pichon et al., 1987)。これらの調査の結果か ら, 付加体形成に伴い, 堆積物の自重による圧密 に加えて，プレートの収束に起因する水平方向の 圧縮作用により，堆積物中から間隙流体が排出さ れ，断層に沿って海底に湧出していると考えられ るようになってきた。また，海底に湧出する湧水 には，水に飽和した堆積物から排出されたもの と, 海底深部のデコルマ付近で起こる堆積岩の変 成過程で発生するものが考えられている（Moore and Saffer et al., 2001)。

南海トラフ以外の付加体を伴う沈み込み帯で も，海底面への間隙流体の湧出が起こっているこ とが示されている。バルバドス付加体ではデコル マで採取された流体の塩素濃度が周辺に比べ顕著 に低いことから，デコルマに沿って流体が排出さ れていると考えられている（Moore et al., 1987）。 コスタリカ沖の中米海溝では，付加体は現在成長 過程にはないとされ，沈み込みに伴う堆積物の 剥ぎとりもほとんどないことから，圧縮により 堆積物中の間隙流体の流出が起こっているとみ られている（Saffer et al., 2000）。また, Saffer et $a l$. (2000) は，沈み达みがはじまる場所から $1.6 \mathrm{~km}$ 陸側で, 過剩間隙水圧が $1.3 \sim 3.1 \mathrm{MPa}$ であることを実験により示している。

\section{III. 熱流量分布}

1980 年代以降，南海トラフから付加体斜面 · 


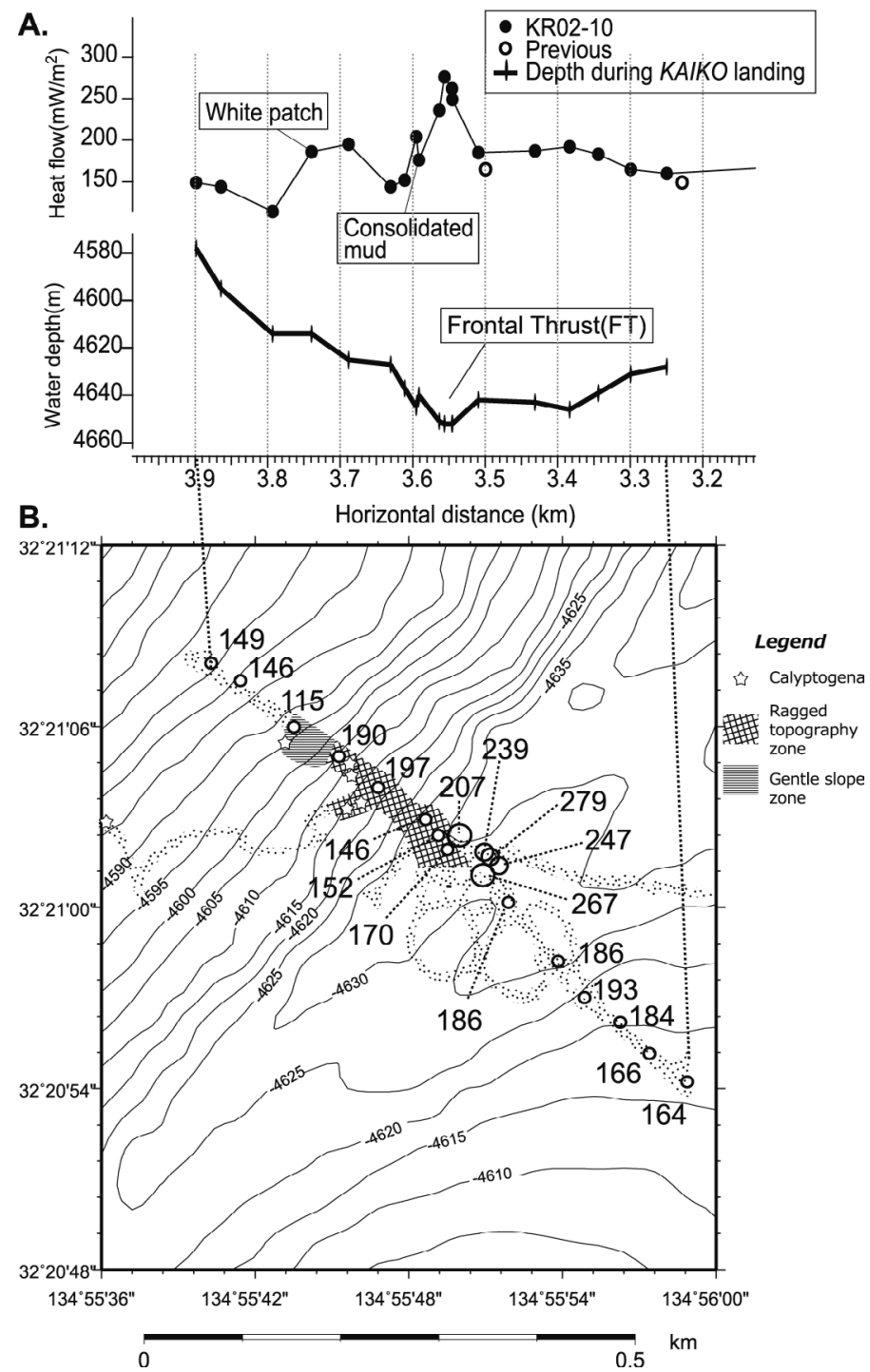

図 2 南海トラフ室戸沖前縁断層先端の熱流量分布とルートマップ. $\mathrm{A}$ ：全縁断層を横切る熱流量観測結果. 黒 丸が調查航海 KR02-10 で測定した観測結果，白丸はそれ以前の熱流量観測結果，黒の太線は無人探査機 「かいこう」の着底深度. B : 無人探査機「かいこう」のルートマップと表層地質図. 大きな白丸は熱流量 観測結果のうちでもとくに值の高い点，小さな白丸はその他の熱流量観測結果.

Fig. 2 Heat flow distribution and route map around of the second frontal thrust at the Nakai Trough off Muroto. A: Heat flow cross-section across the frontal thrust. Solid circles are results obtained during the KR02-10 research cruise; open circles represent previous heat flow data; the heavy line is the water depth during each heat flow measurement acquired by the depth sensor of ROV “KAIKO.” B: Route map along the heat flow survey dives. Bigger open circles indicate especially high heat flow values and smaller open circles are other heat flow data.

前弧海盆にかけて，熱流量観測が盛んに行われて きた（Yamano et al., 1984; 山野・木下, 1989; Yamano et al., 1992 など）（図 2)。潮岬よりも
東部のトラフ底では，多くが $100 \mathrm{~mW} / \mathrm{m}^{2}$ 以下で あり，沈み込むフィリピン海プレートの年代から 推定される熱流量と整合的である（Kinoshita et 


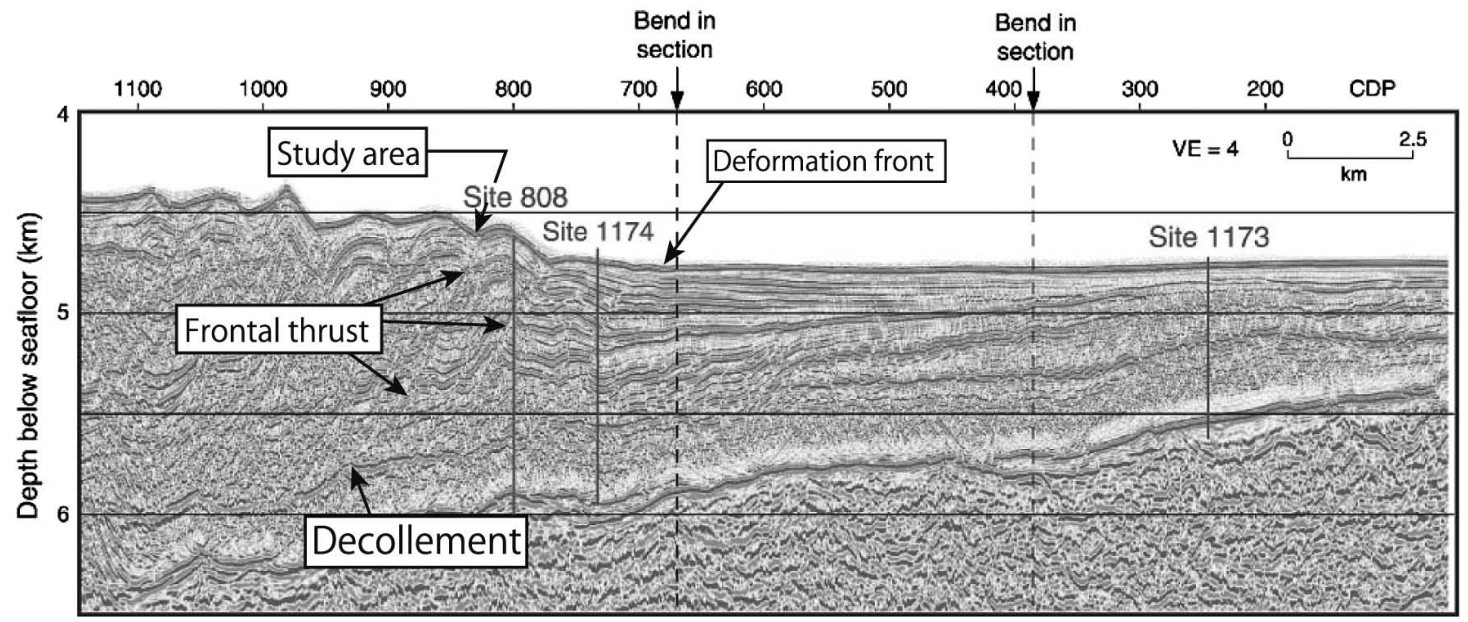

図 3 掘削孔 $1173 ， 1174 ， 808$ を含む反射法地震探査による深度方向の断面図 (Mikada et al., 2002 に加筆). VE は垂直方向への伸長の割合。縦軸は海抜 $0 \mathrm{~m}$ からの深度. 研究領域は, Ocean Drilling Programにより掘削 された掘削孔 $808 よ り$ 陸側にあたり，直下に全縁断層がデコルマまで伸びているのがみえる。また，掘削 孔 808 をデコルマが海底下約 $950 \mathrm{~m}$ 付近で横断していることがみえる. Deformation front の位置は Moore et al.（1991）より引用.

Fig. 3 Seismic depth section across ODP Sites 1173, 1174, and 808 (Mikada et al., 2002). The section is composed of a northwest-trending segment of seismic line 215 through Site 1173, with a diagonal transition to line 281 that passes near Sites 1174 and 808. CDP = common depth point, $\mathrm{VE}=$ vertical exaggeration. Vertical axis is the depth below sea level. Study area is landward from Site 808 of the Ocean Drilling Program, which is just above the frontal thrust, and the frontal thrust extends to the decollement. This image shows that the borehole at Site 808 crosses the decollement at about $950 \mathrm{~m}$ below the seafloor. The location of the deformation front is cited from Moore et al. (1991).

$a l ., 2008) 。$ 一方で，西部の室戸沖南海トラフ上 では，四国海盆の基盤の年令から計算された熱流 量の值よりも観測值が高いという結果が得られて いる（山野ほか, 1997; Yamano et al., 2003）。ま た，変形フロント（図 3) では $200 \mathrm{~mW} / \mathrm{m}^{2}$ に達 する周辺より高い值が観測され（Tokuyama et $a l ., 1995)$, 付加体中の水の絞り出しが原因では ないかと指摘されていた。

このような結果を踏まえ, 2002 年, JAMSTEC で行われた航海（KR02-10）では，無人探査機 「かいこう」により, 南海トラフの付加体前縁部 で熱流量観測を行った。付加体の沈み込みに伴い 形成された逆断層, とくに付加体の前縁断層上で 無人探查機を使用した詳細な熱流量観測を行った 結果，前縁断層直上で，水平 $50 \mathrm{~m}$ 以内の範囲で $280 \mathrm{~mW} / \mathrm{m}^{2}$ の高熱流量值が得られた（Kinoshita and Fujino, 2006)。興味深いのは，高熱流量観
測地点での海底観測の結果では流体の存在を示唆 する場所で報告例の多い，シロウリガイのような 化学合成生態系生物群集はみられなかったことで ある（図 4）。さらに，重要なことに，反射法地 震探査による断面図（図 3） から，とくに熱流量 の高い地点は，二つの褶曲の間にある谷部，前縁 断層直上部と思われる地点にある。

なお，周辺幅 $100 \mathrm{~m}$ の範囲をみたときの平均

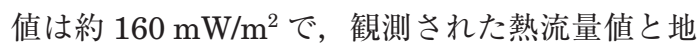
形を照らし合わせても，とくに高い值が前縁断層 直上に集中していることがわかる（図 2)。この 局所的な高熱流量值を中心として, 北西方向，す なわち陸側に向けて熱流量值が減少している傾向 がみられた。

\section{IV. 付加体前縁部の温度・流れ場の推定}

以下に，室戸沖南海トラフの前縁断層出口で観 

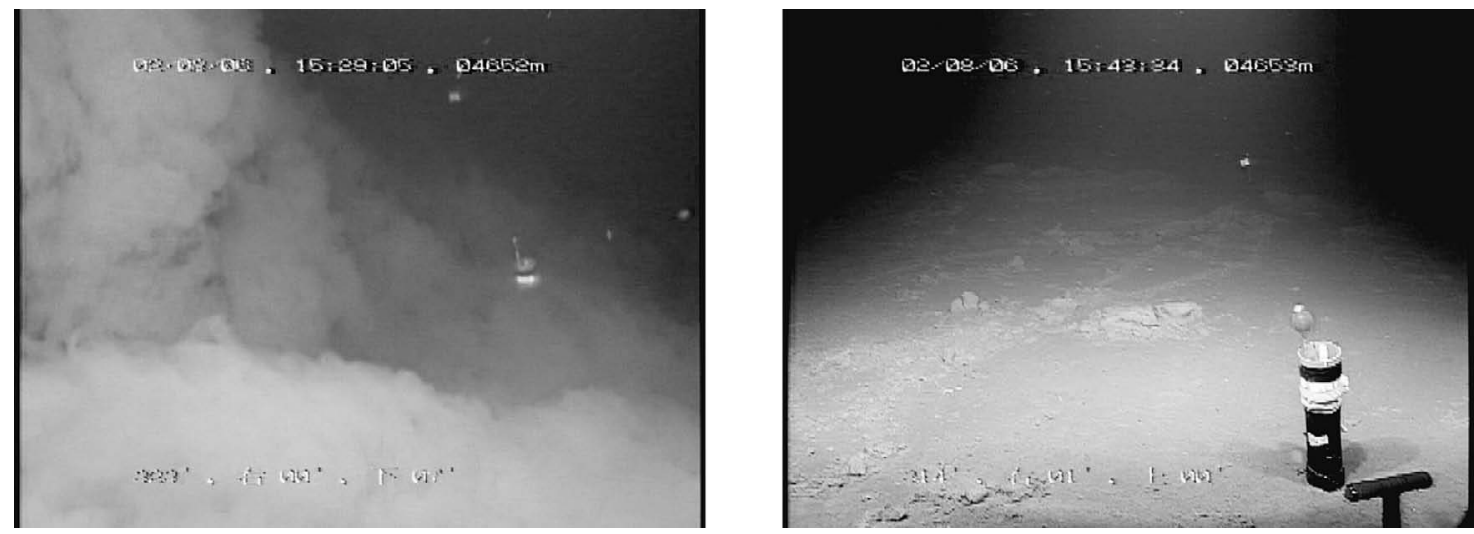

図 4 最も高熱流量を観測した点の周辺の状態. 2 枚の写真はともに $279 \mathrm{~mW} / \mathrm{m}^{2}$ を観測した点で無人探査機「か いこう」により撮影した。周辺には冷湧水を伴う高熱流量発生場周辺で多く観察されるような底生生物群 集はとくにみられない.

Fig. 4 View of surrounding area of highest heat flow point. Two photographs are taken in the point of $279 \mathrm{~mW} / \mathrm{m}^{2}$ by ROV KAIKO. Note that no biological activity was identified in this area.

測された，局所的高熱流量異常の原因を考察す る。上述のように，海底には湧水の直接的な証拠 はないものの, 透水性の前縁断層やデコルマを流 路として間隙流体が上昇すると仮定し，それが掘 削などの結果と整合的であるかどうかを，数值計 算により検証する。また，この数值計算では水の 流れは定常流であると仮定した。具体的には，観 測で得られた前縁断層直上の熱流量異常を最もよ く説明するような，地下浸透率構造とデコルマ内 の過剩間隙水圧の大きさを試行錯誤的に求めた。

今回は単純化のために, 流体湧出の原動力とし て沈み込みによる圧縮により高圧力が発生してい ると考えられるデコルマの陸側の端に過剩間隙水 圧を与え，付加体深部から流体が供給されるモデ ルを考えた（図 5)。デコルマ端にかかる過剩間 隙水圧により, 高浸透率ゾーンとしてデコルマか ら前縁断層に集中的に流体が流れ，前縁断層直上 の高熱流量異常をもたらすと考える。

数值計算に用いたパラメータを表 1 に示す。 2 次元定常条件を仮定して差分法により実施した。 付加体として設定した筐体は水平方向 $2000 \mathrm{~m}$, 深さ $2000 \mathrm{~m}$ の正方形とし, 熱伝導率は Yamano et al. (1992) より深部の值に相当する $2.0 \mathrm{~W} / \mathrm{m} /$ Kを用いた。高浸透率に設定した流路の幅はすべ
て $100 \mathrm{~m}$ に固定した。熱の境界条件として，下 部からの熱流量值 $\left(Q_{\text {base }}\right)$ を観測值から推定され る周辺の值 $150 \mathrm{~mW} / \mathrm{m}^{2}$ として与えた。海底では $0^{\circ} \mathrm{C}$, 左右の境界では断熱とした。また水理的な 境界条件として, 海底を除き流体の通過はないも のとした。

\section{1）支配方程式}

支配する方程式系は，ダルシーの法則による間 隙圧とダルシー速度の構成関係，非圧縮流体を仮 定した質量保存の式，そして間隙流体の移流項を 含む 2 次元熱伝導方程式である。ダルシーの法 則は以下のように書ける：

$$
v=-\left(\frac{k}{\mu}\right) \operatorname{grad}(p-\rho g)
$$

ここで, $\boldsymbol{v}$ は流体の海底面での流出速度, $k$ は浸 透率， $\mu$ は粘性率， $p$ は間隙圧， $\rho$ は間隙流体の 密度, $g$ は重力加速度である。

質量保存の式は，非圧縮流体を仮定すると，

$$
\operatorname{div} v=0
$$

と書ける，(1)，（2）式を連立して $\boldsymbol{v}$ を消去する と, $p$ に関する微分方程式ができる。均質媒体で はこれは $p$ に関するポアソン方程式となるが, 


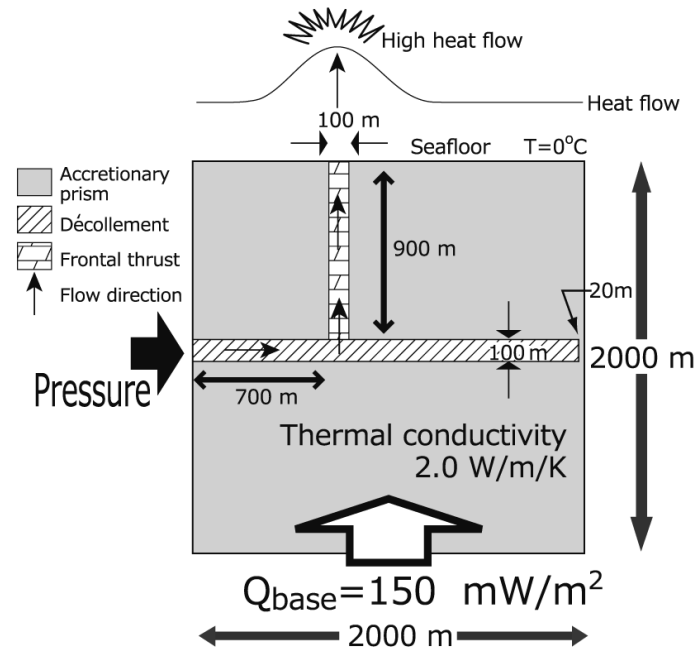

図 5 数值モデルの構造図. 二次元断面図となっており, 水平方向に $2000 \mathrm{~m}$, 深さ方向に $2000 \mathrm{~m}$ の筐体を設 定した。実際の地図（図 1）と照らし合わせると， 左端が陸側の北東方向，右端が海側の南西方向に相 当する.デコルマに相当する高透水性の部分の上図 右端は閉じることで, 現在のデコルマの状態を再現し た。境界面は固定，付加体全体の浸透率を $10^{-17} \mathrm{~m}^{2}$, 熱伝導率は $2.0 \mathrm{~W} / \mathrm{m} / \mathrm{K}$ で一定, 海底面に相当する上 端の温度を $0^{\circ} \mathrm{C}$, 地下から $150 \mathrm{~mW} / \mathrm{m}^{2}$ の熱流量を与 えた。

Fig. 5 Vertical section of two-dimensional numerical model. Model size is $2000 \mathrm{~m}$, both in horizontal and vertical directions. The left side on this model is landward and the right side is seaward (Fig. 1). Decollement and frontal thrust are set as permeable channels. The seaward end of the decollement is hydrologically closed. The permeability and thermal conductivity of the surrounding accretionary prism are fixed at $10^{-17} \mathrm{~m}^{2}$ and $2.0 \mathrm{~W} / \mathrm{m} / \mathrm{K}$, respectively. The temperature on the seafloor is fixed at $0^{\circ} \mathrm{C}$, and the heat flow from the base is set at $150 \mathrm{~mW} / \mathrm{m}^{2}$.

表 1 数值計算で使用したパラメータ. 数值計算のうち, 高透水性の流路の 浸透率 $\left(K_{c h}\right)$ と圧力異常の值 $(\Delta P)$ はそれぞれの計算で変えて与えた.

Table 1 Parameters for numerical model: In the simulation, Permeability within the conduit $\left(K_{c h}\right)$ and pressure anomaly $(\Delta P)$ were assigned as parameters for each calculation.

\begin{tabular}{ll}
\multicolumn{1}{c}{ Parameter } & \multicolumn{1}{c}{ Value } \\
\hline Bottom water temperature & $0^{\circ} \mathrm{C}$ \\
Thermal conductivity & $2.0 \mathrm{~W} / \mathrm{m} / \mathrm{K}$ \\
Thermal diffusivity & $1.0 \times 10^{-6} \mathrm{~m}^{2} / \mathrm{s}$ \\
Bulk density & $1.6 \times 10^{3} \mathrm{~kg} / \mathrm{m}^{3}$ \\
Basement heat flow & $150 \mathrm{~mW} / \mathrm{m}^{2}$ \\
Permeability* & $1.0 \times 10^{-17} \mathrm{~m}^{2}$ \\
Permeability $\left(K_{c h}\right) * *$ & $1.0 \times 10^{-16} \mathrm{~m}^{2}$ to $1.0 \times 10^{-12} \mathrm{~m}^{2}$ \\
Number of grid & $101 \times 101$ \\
Block size & $20 \mathrm{~m} \times 20 \mathrm{~m}$ \\
\hline
\end{tabular}

* Permeability of surrounding area.

** Permeability range of channel area $\left(\right.$ as $\left.K_{c h}\right)$.

ここでは $k, \mu$ が場所, 温度の関数なので, コン

トロールボリューム法により差分化して, 各ス テップでの pを計算した。その $p$ から $\boldsymbol{v}$ を求めた 上で，以下（3）の熱伝導式により各ステップで の温度 $T$ を計算した。実際には定常状態を求め るためにSOR（逐次過緩和）法を用いた。

$$
\rho_{m} c_{m} \frac{\partial T}{\partial t}+\rho_{f} c_{f}(\boldsymbol{v} \cdot \nabla T)=\lambda \Delta T
$$

ここで, $\rho_{m}, c_{m}, \rho_{f}, c_{f}, \lambda$ はそれぞれ固体部 分の密度と比熱, 間隙流体の密度と比熱, 堆積物 全体の熱伝導率である。粘性率 $\mu$ は温度に敏感で あるので, 以下の (4) 式 (American Society of 
Mechanical Engineers, 1967）により逐次計算し た :

$$
\mu=241.4 \times 10^{-7} \times \exp \left(\frac{570.58}{T+273.15}-140\right)
$$

なお， $\rho_{f}$ は熱膨張の効果を考慮すべきである が，ここでは温度変化が小さいので一定とした。

\section{2）流路の位置・形状}

本計算を実施するにあたり，まず，流路の位 置・形状をこれまでに得られた地震探査や掘削結 果を参考にして固定とした（図 5)。まず，ODP サイト 808 の掘削結果では，デコルマの位置が 海底面から深度 $945 \mathrm{~m}$ 付近で厚さが約 $30 \mathrm{~m}$ と されている（Mikada et al., 2005）（図 3）。この 位置を参考に，デコルマに相当する水平の流路 深度 900 ～ $1000 \mathrm{~m}$ の区間とし，デコルマの海側 の端（図 5 の右端側）は閉じた。流路の浸透率 $10^{-15} \mathrm{~m}^{2}$ ，過剩間隙水圧 $10 \mathrm{MPa}$ で計算を行った 結果から，前縁断層の位置は付加体海側に相当す る始点 (左端, 図 5 参照) から水平距離 700 $800 \mathrm{~m}$ の位置に決定した。また計算の単純化の ために前縁断層に相当する高透水帯の形状は垂直 とし，デコルマから海底まで一定の浸透率をもっ た流路とした。加えて, 流路の幅および厚みはす べての場所で $100 \mathrm{~m}$ として設定した。Mikada et al.（2005）が示すデコルマと前縁断層の值に比 べ大きいが，実際どの程度デコルマの厚みが熱の 移動に関与しているかは現在不明であるので，今 回のは予備計算の趣旨のもと, 単純化してこの值 とした。

\section{3）付加体での浸透率}

付加体での浸透率は，既存の見積もり（Bekins et al. (1995), Carson and Screaton (1998), Saffer and Bekins (1998), Saffer and Bekins (2002), Kato et al. (2004), Mikada et al. (2005)）を参考とした。すなわち，断層以外の 場所では $10^{-15} \sim 10^{-20} \mathrm{~m}^{2}$, 前縁断層では $10^{-14} \sim$ $10^{-19} \mathrm{~m}^{2}$ ，デコルマでは $10^{-10} \sim 10^{-19} \mathrm{~m}^{2}$ の範 囲と考えた。これに基づき，本論に使用する概念 モデルでは，流路（前縁断層とデコルマ）の浸透 率を未定パラメータとし，その範囲を $10^{-12}$
$10^{-16} \mathrm{~m}^{2}$ で変化させた。また，簡略化のため， 周辺の付加体の浸透率は全計算を通して $10^{-17} \mathrm{~m}^{2}$ に固定した。

以上まとめると，本計算では，流路の浸透率 $\left(K_{c h}\right)$ とデコルマ端での過剩間隙水圧 $(\Delta P)$ を パラメータとし，表面での熱流量分布をもっとも よく説明するようなこれらのパラメータの組み合 わせを試行錯誤的に求めるという方法をとった。

\section{V. 数値計算の結果}

計算に用いたパラメー夕 $\left(K_{c h}, \Delta P\right)$ の組み 合わせは約 500 通りである。それぞれについて， 温度・圧力場を計算し，表面での熱流量とダル シー速度分布を出力した。今回は計算に用いた高 浸透率に設定した流路の幅を $100 \mathrm{~m}$ に固定して いるので，以下では流路中央における最大值 $Q_{\max }$ のみを用いて議論を行う。

なお，前縁断層の位置（圧力源であるデコルマ 左端からの水平距離）は図 5 では $700 \mathrm{~m}$ に固定 しているが, この距離を変えた影響を検討した。 その結果， $K_{c h}$ や $\Delta P$ が同じでも，前縁断層が圧 力源に近いほど $Q_{\max }$ が大きくなることがわかっ た。たとえば，圧力源から前縁断層までの距離が $700 \mathrm{~m}\left(10 \mathrm{MPa}, 10 \mathrm{~m}^{2}\right)$ で $Q_{\max }$ が $280 \mathrm{~mW} / \mathrm{m}^{2}$ と計算されるが，前縁断層までの距離が $300 \mathrm{~m}$ のときは $450 \mathrm{~mW} / \mathrm{m}^{2}, 1700 \mathrm{~m}$ では $200 \mathrm{~mW} / \mathrm{m}^{2}$ 程度と変動した。定性的には，距離が離れると $Q_{\max }$ の距離依存性はなくなるようである。断層 の距離は，今回の計算で適宜設定した人為的なも のであるので，今回は， $Q_{\max }$ の距離依存性はあ まりみられなくなるような距離として，700 m を 採用した。

図 6 に，代表的な $K_{c h}$ および $\Delta P$ について計算 された $Q_{\max }$ の関係を示す。当然ながら， $Q_{\max }$ は $K_{c h}$ が高い值であるほど，また $\Delta P$ が大きいほど 高い。さらに，図 $6 \mathrm{~A}$ にあるように, $Q_{\max }$ の值が $300 \mathrm{~mW} / \mathrm{m}^{2}$ よりも低い範囲では， $\Delta P$ と $Q_{\max }$ は 比例関係にあることがわかった。また図 $6 \mathrm{~B}$ をみ ると，その比例係数 $\mathrm{G}_{q p}\left(=\mathrm{d}\left(Q_{\max }\right) / \mathrm{d}(\Delta P)\right)$ は流路の浸透率 $K_{c h}$ に比例しているようにみえ る。 

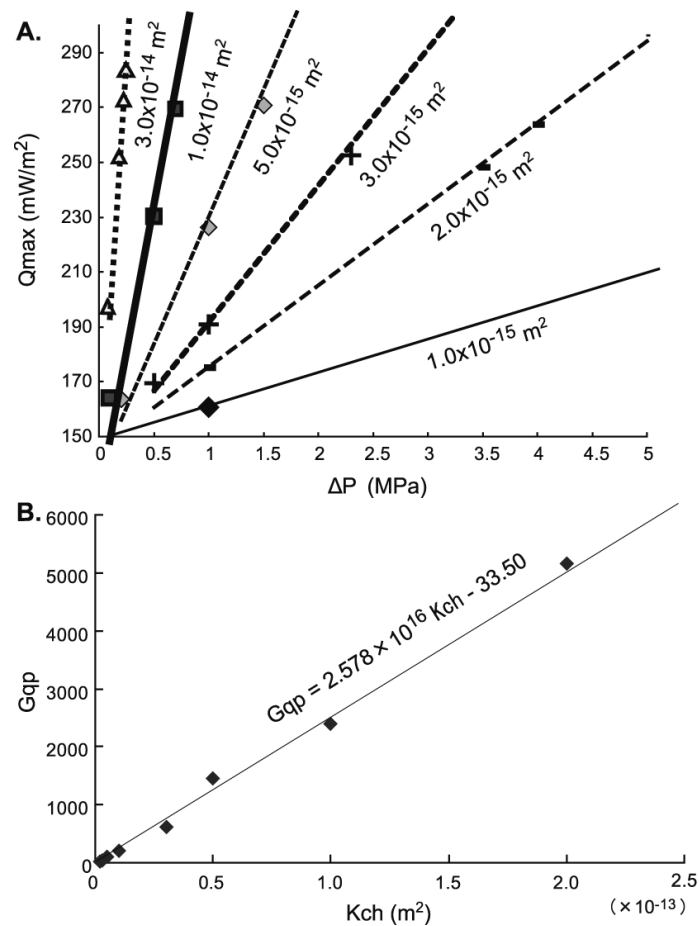

図 6 数值計算の結果対熱流量とダルシー速度. 計 算による結果のうち, 熱流量のピーク值と流 速のピーク值を比較したもの。縦軸は流速, 横軸は熱流量を示す。図中の直線はプロット した值に対する近似直線で，添え字は近似直 線に值する式. 扮打むね, 直線に近似するこ とができる

Fig. 6 Simulation result of surface heat flow vs. Darcy velocity. Both values are picked from their peak values. Solid line is the latest-squares fit to a straight line, which gives a good approximation to the data.

なお $K_{c h}$ に周辺の浸透率 $\left(K_{0}\right) \quad 10^{-17} \mathrm{~m}^{2}$ と同 值を与えた場合, 压力 $(\Delta P)$ が上昇しても, $Q_{\text {max }}$ はその周辺の值とまったく同じであり, $Q_{\text {base }}\left(150 \mathrm{~mW} / \mathrm{m}^{2}\right)$ のままであった。これは計算 過程が適正であることを示すと同時に, $10^{-17} \mathrm{~m}^{2}$ 程度である場合には，この系の熱移動が熱伝導に 支配されていることを示している。

以上から， $Q_{\max }$ は $K_{c h}$ と $\Delta P$ の積に比例すると いうモデルを考えた図 7 に $Q_{\max }$ を縦軸, $K_{c h} \times$ $\Delta P$ を横軸にとったプロットを示すが，両者に 良好な比例関係があることがみてとれる。この
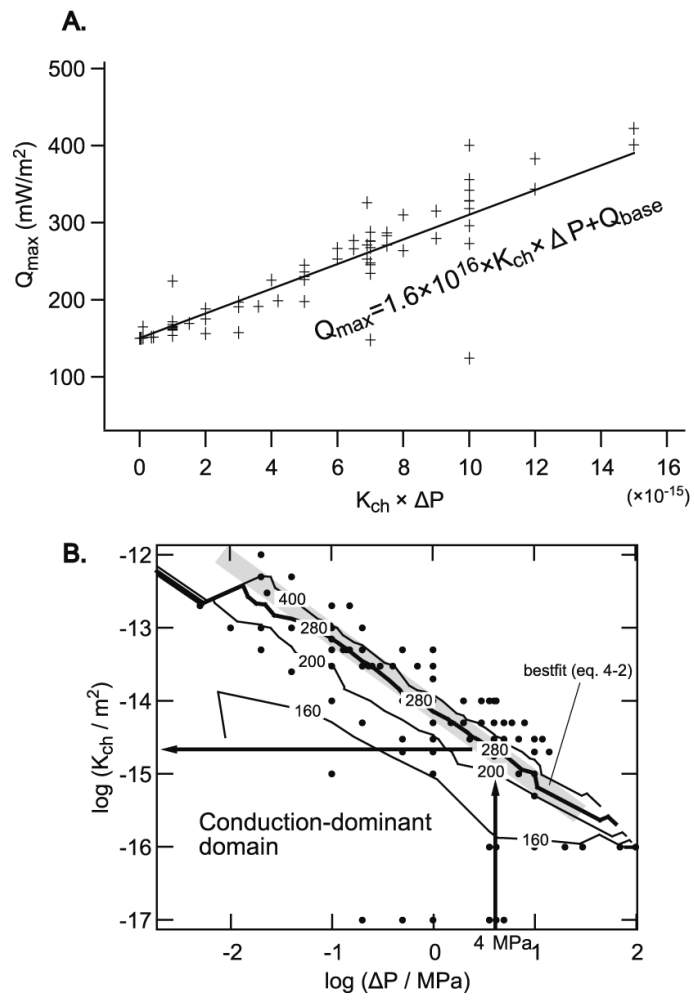

図 7 数值計算の結果. $\mathrm{A}$ : 熱流量と流路の浸透率, 圧力の積の関係. 熱流量の值はそれぞれの計 算で得たピークの值をとっている，横軸はそ れぞれの計算で与えた $K_{c h}$ と $\Delta P$ の積. $\mathrm{B}$ ：計 算で得たパラメー夕, $\Delta P, K_{c h}$ に対して計算 された $Q_{\max }$ の分布（○印とコンター，単位 $\left.\mathrm{mW} / \mathrm{m}^{2}\right)$. 黒い太線のコンターは観測された熱 流量值 $\left(280 \mathrm{~mW} / \mathrm{m}^{2}\right)$ に対応する。.太い直線 （灰色）は，最適解を示す（5）式に対応し，そ の右下端は間隙圧異常が $4 \mathrm{MPa}$ の位置を示す. 左下の領域は $Q_{\max }$ が約 $150 \mathrm{~mW} / \mathrm{m}^{2}$ で一定であ り，基本的には間隙水流動のない領域.

Fig. 7 Summary plots of numerical simulation. A: Maximum heat flow on the seafloor $\left(Q_{\max }\right)$ vs. the product of $K_{c h}$ and $\Delta P$. A least-squares fitting is applied and is shown as a solid line. The best-fit values of $K_{c h} \times \Delta P$ for the observed maximum heat flow $\left(280 \mathrm{~mW} / \mathrm{m}^{2}\right)$ is estimated as $8.0 \times$ $10^{-15}$. B: Calculated heat flow $\left(Q_{\max }\right)$ distribution in the $\Delta P-K_{\text {ch }}$ parameter space. Dots represent points where calculations were performed, and the numbers attached to contour lines indicate $Q_{\max }$ in $\mathrm{mW} / \mathrm{m}^{2}$. Gray bold line is the best-fit solution corresponding to equation (5). The lowerleft domain on this graph has a constant value of $\sim 150 \mathrm{~mW} / \mathrm{m}^{2}$, indicating no substantial fluid advection. 
ことは，本モデルでは，観測された熱流量異常 $\left(Q_{\text {max }}\right)$ を説明するような流体の流路の浸透率と 間隙圧異常を独立に決めることはできないことを 示す。

図 7A に示す関係から, 最小二乗法でフィット して $Q_{\max }$ と $K_{c h} \times \Delta P$ の関係を以下のように示 すことができる：

$$
Q_{\max }=1.6 \times 10^{16} \times K_{c h} \times \Delta P+Q_{\text {base }}
$$

この式は，本計算に用いたモデルの特性を示す ものである。熱流量と断層の浸透率，およびダル シー流の原動力としての間隙圧異常の間の関係を 示すものといってもよい。

（5）式から，観測結果である $Q_{\max }=280 \mathrm{~mW} /$ $\mathrm{m}^{2}$ に対応する $K_{c h} \times \Delta P$ の值は $8 \times 10^{-15}$ となる。 図 $7 \mathrm{~B}$ は, $\Delta P, K_{c h}$ に対して計算された $Q_{\text {max }}$ の 分布を表現したものである。太線のコンターは観 測された熱流量值 $\left(280 \mathrm{~mW} / \mathrm{m}^{2}\right)$ に対応する。 左下の領域は $Q_{\max }$ が約 $150 \mathrm{~mW} / \mathrm{m}^{2}$ で一定であ り，基本的には間隙流体の移動のない領域であ る。両対数グラフなので（5）式は直線関係にな るが，図 7Bではこれを灰色のゾーンで示した。 太線コンターにほほ対応していることがわかる。

\section{VI. 考察}

本数值モデルでは, 室戸沖デコルマ・前縁断層 において，(5) 式，あるいは図 7B のような，浸 透率と過剩間隙水圧の関係が成り立つことを示す ことができた。この関係をもとに，掘削などによ り得られている既存の結果をあわせて, これらの パラメー夕を絞り込むことを試みる。

Screaton et al.（2002）は, 室戸沖トラフ底で の掘削結果からデコルマでの間隙圧を推定した。 プレート収束運動による圧縮変形を起こす前の 地点（ODP 掘削サイト 1173）での間隙率の深さ 分布を基準とし, 変形直前地点（掘削サイト 1174），および初期変形地点（掘削サイト 808） における值と比較し，その差が過剩間隙水圧に起 因すると仮定して，デコルマおよびその下での過 剩間隙水圧を，掘削サイト 1174 では $3.6 \mathrm{MPa}$, 掘削サイト 808 では $4.2 \mathrm{MPa}$ と求めた。この值
が，本モデルにおける $\Delta P$ に相当すると考えられ る。ただし実際には，バルバドス付加体でみられ るように（Tokunaga, 2000), デコルマからの流 体移動は前縁断層のみでなく周辺の高浸透率の部 分にも起こっていると考えられるから，前縁断層 に発生している過剩間隙水圧值はもっと低いだろ

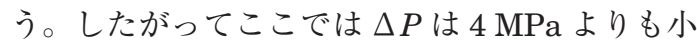
さい值であるとする。

図 7B に掘削サイト 808 における過剩間隙水圧 值の最大值をあてはめると，デコルマ（および前 縁断層）の浸透率 $K_{c h}$ は $2 \times 10^{-15} \mathrm{~m}^{2}$ 以上でな くてはならないことが示される。今回のモデルで は, 周囲の浸透率を $10^{-17} \mathrm{~m}^{2}$ としているので, デコルマ等の浸透率が周囲より約 2 桁，あるい はそれ以上大きいことを示す。

断層やデコルマの浸透率についての議論 (Saffer and Bekins, 1998, Carson and Screaton, 1998, Kato et al., 2004）では, 流路の浸透率は付加体 全体の值に比べて高いと主張している。Saffer and Bekins（1998）は，定常状態での南海付加 体の水理学的モデル計算から，定常状態でのデコ ルマの浸透率は $10^{-17} \mathrm{~m}^{2}$ 以上でなくてはならな いことを示した。一方で，南海トラフ室戸沖デコ ルマ付近で観測された低塩素濃度異常をデコルマ 付近におけるスメクタイトからの脱水であるとし て行った計算では, 定常的な流れではこの異常を 説明できないことを示した。水圧破砕等のイベン トが起こってデコルマの浸透率が周囲より $3 \sim 4$ 桁高くなり，その結果生じる間隙流体の移動が必 要だと主張している。

また Bourlange et al. (2003) は，掘削サイト 808 で得られた孔内検層結果から間隙率を計算 し，それに基づいてデコルマ帯（15～20 m 幅） の過剩間隙水圧が $4 \mathrm{MPa}$ 程度であると推定した。 このような異常は一時的な現象であり，その原因 が 1946 年の南海地震だとすると, 震源域から掘 削サイトに圧力異常が到達するためには $500 \mathrm{~m} /$ yr の速度が必要で，その流れを可能にするため にはデコルマの浸透率が $10^{-12} \mathrm{~m}^{2}$ でなくてはな らない, と主張した。また周囲の浸透率が $10^{-18}$ 〜 $10^{-19} \mathrm{~m}^{2}$ であり，ダルシー流による拡散によって 
デコルマの過剩間隙水压が減衰するには 100 1000 年を要する, と推定した。

Ge and Screaton（2005）は，過剩間隙水圧の 生ずる原因を地震発生による変位に起因する一時 的な変動であると計算した。また Yamano et al. （1992）も，熱流量異常を説明する流れ場が局所 的，あるいは非定常的である可能性を示した。

これらの見積もりを今回の計算結果と比較する 上で，今回の数值計算は定常状態を仮定している ことに留意する必要がある。言い換えると，観測 された熱流量異常を説明するための $K_{c h} \times \Delta P$ の 最小值を計算していることになる。非定常の場合 には，この值はさらに大きいことが要請される。 上記の議論では，デコルマでの過剩間隙水圧はせ いぜい $4 \mathrm{MPa}$ とされるため， $K_{c h}$ はさらに大き いことが必要となる。

一方，Saffer and Bekins（1998）によれば, こうした圧力異常が発生することによる影響 は $100 \mathrm{kyr}$ 程度継続すると述べている。また Screaton et al.（2002）は，デコルマでの過剩間 隙水圧は，付加体深部での間隙流体が非排水条件 下にあると考えなければ高すぎると主張した。し たがって，本計算で扱う範囲では，定常状態を仮 定してもそれほど実体と離れていない可能性があ る。

塩素濃度・過剩間隙水圧を説明するためには周 囲より $3 \sim 4$ 桁大きい浸透率が要請されたのに 対し，今回の計算では熱流量異常を説明するため には，浸透率は 2 桁以上高いという結果であっ た。一桁程度のずれはやむを得ないとも考えられ るが, 熱や化学組成の異常が, 断層帯内部を通過 した流体の「総量」に依存するならば，総量は断 層帯の幅と浸透率の積に比例するので，今回の計 算で断層の幅を実際よりも広くとったことがこの 違いを生じた原因かもしれない。

今回の計算は予備的なものであるために，これ 以上の議論は無理がある。しかしながら，掘削な どの結果から推定した浸透率・過剩間隙水圧の範 囲で，おおむね今回の熱流量異常が説明できたこ とから，前縁断層で観測された熱流量異常に湧水 が関係していることはいえそうである。

\section{VII.おわりに}

2002 年に南海トラフ室戸沖で実施した詳細な 熱流量観測の結果，付加体の前縁断層上 $50 \mathrm{~m}$ 以内の範囲で最高 $280 \mathrm{~mW} / \mathrm{m}^{2}$ の高熱流量值が 得られた。熱流量は前縁断層直上の高熱流量観 測点から，測線の南東，北西方向に向かって約 $150 \mathrm{~mW} / \mathrm{m}^{2}$ まで減少しており，また全体をみる と, 海側から陸方向に向かって減少している傾向 もみられた。

高熱流量観測点では湧水の直接の証拠はないも のの，透水性の前縁断層やデコルマを流路として 間隙流体が上昇すると仮定し，それが掘削などの 結果と整合的であるかどうかを，数值計算により 検証した。流路の浸透率 $\left(K_{c h}\right)$ とデコルマ端で の過剩間隙水圧 $(\Delta P)$ をパラメータとし, 2 次 元定常状態で水理・熱連成系を数值的に解いて, 表面での熱流量分布をもっともよく説明するよう なこれらのパラメータの組み合わせを試行錯誤的 に求めた。その結果, 断層上の最大熱流量は $K_{c h}$ と $\Delta P$ の積に比例することが判明した。このこと は，本モデルでは観測された熱流量異常 $\left(Q_{\max }\right)$ を説明するような流路における浸透率と過剩間隙 水圧を独立に決めることはできないことを示唆す る。

ODP による掘削結果から推定された，室戸沖 デコルマでの過剩間隙水圧は最大 $4 \mathrm{MPa}$ である。 数值計算の結果から，デコルマおよび前縁断層の 浸透率は $2 \times 10^{-15} \mathrm{~m}^{2}$ 以上（あるいは周囲より 約 2 桁以上大きい) ことが示された。デコルマ 付近の塩素濃度異常を説明するために，デコルマ が破砕されて浸透率が $3 \sim 4$ 桁上昇するという イベントが必要であるとされるが，数值計算の結 果はお抄むね整合的である。すなわち，前縁断層 で観測された熱流量異常が断層に沿った流体の湧 水活動と関係していることが示唆された。

今後の課題として，数值計算においては非定常 状態の導入などより精密なモデルを作成するこ と，熱流量観測ではより陸側の付加体方向，海方 向での熱流量観測が必要であろう。 


\section{謝 辞}

本論文では，JAMSTEC，KR02-10 航海で得たデー 夕を使用した。かいれいKR02-10 航海では湯川 修船 長, 平田和好運航長率いる無人探査機「かいこう」運 航チームをはじめとする乗組員の皆様，観測支援員の 樋泉昌之氏, KR02-10 乗船研究者の方々には航海中 大変お世話になりました。また，九州大学工学研究院 江原幸雄教授に貴重なご助言をいただきました。二人 の匿名査読者および編集委員の方々に，原稿を注意深 くお読みいただき適切な助言をいただきました。ここ に御礼申し上げます。

\section{文献}

American Society of Mechanical Engineers (1967): Thermodynamic and Transport Properties of Steam: Comprising Tables and Charts for Steam and Water, Calculated Using the 1967 IFC Formulation for Industrial Use in Conformity with the 1963 International Skeleton Tables, as Adopted by the Sixth International Conference on the Properties of Steam. American Society of Mechanical Engineers.

芦 寿一郎・平 朝彦 (1989): クーロンウェッジモデ ルからみた南海トラフ付加体の構造. 月刊地球, 11, 744-748. [Ashi, J. and Taira, A. (1989): Chikyu Monthly, 11, 744-748.]

芦 寿一郎・倉本真一・森田澄人 · 角皆 潤 - 後藤 秀作 - 小島茂明 - 岡本拓士 - 石村豊穂 - 井尻 明 · 土岐知弘・ 工藤新吾 - 淺井聡子 - 内海真生 (2002): 熊野沖南海トラフ付加プリズムの地質構造と冷湧 水一YK01-04 Leg2 熊野沖調查概要一. JAMSTEC 深海研究, 20, 1-8. [Ashi, J., Kuramoto, S., Morita, S., Tsunogai, U., Goto, S., Kojima, S., Okamoto, T., Ishimura, T., Ijiri, A., Toki, T., Kudo, S., Asai, S. and Utsumi, M. (2002): JAMSTEC Journal of Deep Sea Research, 20, 1-8.]

Bekins, B.A., McCaffrey, A.M. and Dreiss, S.J.(1995): Episodic and constant flow models for the origin of low-chloride waters in a modern accretionary complex. Water Resources Reseach, 31, 3205-3215.

Bourlange, S., Henry, P., Moore, J.C., Mikada, H. and Klaus, A. (2003): Fructure porosity in decollement zone of Nankai accretionary wedge using Logging While Drilling resistivity data. Earth and Planetary Science Letters, 209, 103-112.

Carson, B. and Screaton, E.J. (1998): Fluid flow in accretionary prism. Evidence for focused timevariable discharge. Reviews of Geophysics, 36, 329351.

Fiala-Médioni, A., Boulégue, J., Ohta, S., Felbeck, H. and Mariotti, A. (1993): Source of energy sustaining the Calyptogena populations from deep trenches in subduction zones off Japan. Deep-Sea Reseach $I, 40,1241-1258$.

Ge, S. and Screaton, E. (2005): Modeling seismically induced deformation and fluid flow in the Nankai subduction zone. Geophysical Research Letters, 32, L17301 doi:10.1029/2005GL023473.

石井輝秋 - 佐藤 暢 - 町田嗣樹 - 原田 悟 - 臼井 朗 石塚 治・谷口英嗣・八木和徳 (2000): 紀南海山列 と伊豆一小笠原背弧雁行海山列の地質学的 ·岩石学 的研究. 地質調查所月報, 51，615-630. [Ishii, T., Sato, H., Machida, S., Harada, S., Usui, A., Ishizuka, O., Taniguchi, H. and Yagi, K. (2000): Bulletin of the Geological Survey of Japan, 51, 615-630.]

笠原順三・鳥海光弘・河村雄行 (2003): 地震発生と 水一地球と水のダイナミクス. 東京大学出版会. [Kasahara, J., Toriumi, M. and Kawamura, K. (2003): The Role of Water in Earthquake Generation. Uninersity of Tokyo Press.]

Kato, A., Sakaguchi, A., Yoshida, S., Yamaguchi, H. and Kaneda, Y. (2004): Permeability structure around an ancient exhumed subduction fault. Geophysical Research Letters, 31, L06602, doi:10.1029/2003GL019183.

Kinoshita, M. and Fujino, K. (2006): Possible pore pressure anomaly at decollement inferred from localized heat flow anomaly at the toe of Nankai accretinary prism off Muroto. Eos, Transactions, $A G U$, Fall Meeting Abstract, T11G-08.

Kinoshita, M., Kanamats, T., Kawamura, K., Shibata, T., Hamamoto, H. and Fujino, K. (2008): Heat flow distribution on the floor of Nankai Trough off $\mathrm{Ku}$ mano and implications for the geothermal regime of subducting sediments. JAMSTEC Report of Research and Developmen, 8, 13-28.

Le Pichon, X., Iiyama, T., Boulegue, J., Charvet, J., Faure, M., Kano, K., Lallemant, S., Okada, H., Rangin, C., Taira, A., Urabe, T. and Ueda, S. (1987): Nankai Torugh and Zenisu Ridge: A deep-sea submerisible survey. Earth and Planetary Science Letters, 87, 285-299.

Mikada, H., Becker, K., Moore, J.C., Klaus, A., et al. (2002): Proceedings of the Ocean Drilling Program, Initial Reports. 196, College Station, TX (Ocean Drilling Program).

Mikada, H., Moore, G.F., Taira, A., Becker, K., Moore, J.C. and Klaus, A. eds. (2005): Proceedings of the Ocean Drilling Program, Scientific Results. 190/196, College Station, TX (Ocean Drilling Program).

Moore, J.C. and Saffer, D. (2001): Updip limit of the seismogenic zone beneath the accretionary prism of southwest Japan: An effect of diagenetic to lowgrade metamorphic process and increasing effective stress. Geology, 29, 183-186.

Moore, J.C., Mascle, A., Taylor, E., Andreieff, P., Alvarez, F., Barnes, R., Beck, C., Behrmann, J., Blanc, G., Brown, K., Clark, M., Dolan, J., Fisher, A., Gieskes, J., Hounslow, M., McClellan, P., Moran, K., Ogawa, Y., Sakai, T., Schoonmaker, J., Vrolijk, P., Wilkens, R. and Williams, C. (1987): Expulsion of fluids 
from depth along a subduction-zone decollement horizon. Nature, 326, 785-788.

Moore, G.F., Kang, D.E., Shipley, T.H., Taira, A., Stoffa, P.L. and Wood, W.T. (1991) : Structual framework of the ODP Leg 131 area, Nankai Trough. Proceedings of the Ocean Drilling Program, Initial Reports, 131, 15-20.

Saffer, D.M. and Bekins, B.A. (1998): Episodic fluid flow in the Nankai Trough accretionary complex. Timescale, Geochemistry, flow rates, and fluid baget. Journal of Geophysical Research, 103, 3035130370.

Saffer, D.M. and Bekins, B.A. (2002) : Hydrologic controls on the morphology and mechanics of accretionary wedges. Geology, 30, 271-274.

Saffer, D.M., Silver, E.A., Fisher, A.T., Tobin, H. and Moran, K. (2000): Inferred pore pressures at the Costa Rica subduction zone: Implications for dewatering processes. Earth and Planetary Science Letters, 177, 193-207.

Screaton, E., Saffer, D., Henry, P. and Hunze, S. (2002): Porosity loss within underthrust sediments of the Nankai accretionary complex. Implications for overpressures. Geology, 30, 19-22.

Taira, A., Hill, I., Firth, J. et al. (1991): Proceedings of the Ocean Drilling Program, Initial Reports. 131, Ocean Drilling Program, College Station, TX (Ocean Drilling Program).

Taira, A., Hill, I., Firth, J., Berner, U., Brückmann, W., Byrne, T., Chabernaud, T., Fisher, A., Foucher, J.-P., Gamo, T., Gieskes, J., Hyndman, R., Karig, D., Kastner, M., Kato, Y., Lallemant, S., Lu, R., Maltman, A., Moore, G., Moran, K. et al. (1992): Sediment deformation and hydrogeology of the Nankai Trough accretionary prism: Synthesis of shipboard results of ODP Leg 131. Earth and Planetary Science Letters, 109, 431-450.
Toki, T., Tsunogai, U., Gamo, T., Kuramoto, S. and Ashi, J. (2004): Detection of low-chloride fluids beneath a cold seep field on the Nankai accretionary wedge off Kumano, south of Japan. Earth and Planetary Science Letters, 228, 37-47.

Tokunaga, T. (2000): The role of turbidites on compaction and dewatering of underthrust sediments at the toe of the northern Barbados accretionary prism: New evidence from Logging While Drilling, ODP Leg 171A. Earth and Planetary Science Letters, 178, 385-395.

Tokuyama, H., Shcheka, S., Isezaki, N., Vysotskiy, S., Kulinich, R., Karp, B., Lelikov, E., Fujioka, K. and Liu, G. eds. (1995): Geology and Geophysics of the Philippine Sea. Terrapub, 406p.

山野 誠・木下正高 (1989): 南海トラフの熱流量分布 と間隙水循環. 月刊地球，11，651-656. [Yamano, M. and Kinoshita, M. (1989): Chikyu Monthly, 11, 651-656.]

Yamano, M., Honda, S. and Uyeda, S. (1984): Nankai Trough: A hot trench?. Marine Geophysical Researches, 6, 187-203.

Yamano, M., Foucher, J.-P., Kinoshita, M., Fisher, A., Hyndman, R.D. and ODP Leg131 Shipboard Scientific Party (1992): Heat flow and fluid flow regime in the western Nankai accretionary prism. Earth and Planetary Science Letters, 109, 451-462.

山野 誠・木下正高・ 山形尚司 (1997): 日本列島周辺 海域の地殼熱流量分布。地質ニュース, 517, 1219. [Yamano, M., Kinoshita, M. and Yamagata, T. (1997): Chishitsu News, 517, 12-19.]

Yamano, M., Kinoshita, M., Goto, S. and Matsubayashi, O. (2003): Extremely high heat flow anomaly in the middle part of the Nankai Trough. Physics and Chemistry of the Earth, 28, 487-497.

(2010 年 3 月 17 日受付, 2010 年 10 月 18 日受理) 